\title{
1. Introduction: the legacy of the Reagan revolution
}

In the years after Ronald Reagan left office in January 1989, there were few on the right who did not hail the 40th president's greatness or seek to claim his political mantle. William F Buckley, founding editor of National Review, called for Reagan to be placed amongst the most well-known pantheon of heroic presidential figures: "Reagan belongs on Mount Rushmore, and he'll be there, after the carpers die off" (quoted in Bjerre-Poulsen, 2008: 209). Certainly, few Republicans failed to cite Reagan as an inspiration. Jonah Goldberg, senior editor at National Review, irreverently observed that Republican candidates for public office, particularly those seeking the presidential nomination, always declare in the style of the rebel slaves in the film Spartacus, "I'm Ronald Reagan!" “No, I'm Ronald Reagan!” (Goldberg, 2016).

For some, a substantial part of Reagan's greatness lay in his political personality. Despite his long engagement with politics he had been able to frame himself, and was framed by others, as an outsider who had overcome the barriers imposed by established and self-serving policy elites. He followed in the footsteps of Senator Barry Goldwater's 1964 election campaign by challenging the eastern establishment's former hold over Republicanism, and while unsuccessful in his bid for the party's 1976 presidential nomination, was victorious just four years later. Others pointed to the optimistic vision and buoyancy that he appeared to convey and the ways in which he seemingly crossed the class divide. Ed Meese, his 1980 campaign manager and later Attorney-General, said optimism was "just such a natural characteristic of Ronald Reagan that it was implicit in everything we did" (quoted in White, 2008). This attribute enabled him to win votes in both 1980 and 1984 and construct a coalitional bloc that not only stretched beyond the party faithful but also enabled the Republicans to secure the support of former Democratic voters, often referred to as "Reagan Democrats".

Even more importantly for the conservative faithful, the Reagan legacy also rested upon what was represented as a dramatic and ruptural policy revolution that transformed the country as well as its place in the world whilst also reconfiguring the meaning of both conservatism and Republicanism. Whatever the empirical realities of the Reagan White House, the narratives underpinning the concept of a "Reagan revolution" in the 1980s were structured around reduc- 
tions in the size and scope of government, the dismantling of regulation, cuts in taxation rates, the curbing of dependency upon government, the rollback of cultural progressivism and the appointment of federal judges who would curb the trend towards what was regarded as the making of social policy through judicial activism.

\section{FOREIGN POLICY}

If foreign and national security policy is considered, Reaganism became synonymous with what conservatives of almost all hues represented as the reconstruction of the US's strategic and military prowess. The Reagan administration seemed to redeem the nation after the foreign policy setbacks and humiliations of the 1970s. And, although the Berlin Wall fell 11 months after he left office, he was the president who won the Cold War. The neoconservative Project for a New American Century, which was founded in 1997, defined its purpose by calling for a "Reaganite policy of military strength and moral clarity" (quoted in Schonberg, 2009: 87). Five years before this, Patrick J Buchanan, Reagan's former Director of Communications who later sought the Republican presidential nomination and embraced a "paleo-conservative" gospel that broke with many of the defining tenets of Reaganism, always paid lavish tribute to his former boss. In his speech to the 1992 Republican national convention, Buchanan said in terms that would be echoed across the right: "Ronald Reagan made us proud to be Americans again. We never felt better about our country; and we never stood taller in the eyes of the world than when the Gipper was at the helm" (Buchanan, 1992).

\section{BRINGING FUSIONISM TO FRUITION}

By drawing together economic freedom, cultural traditionalism and the rebuilding of military capacity, Reagan and Reaganism brought to fruition the fusionism that William F Buckley and Frank Meyer had developed in the 1950s through National Review. Fusionism had united those who looked towards figures such as Russell Kirk, the scholar and commentator whose conservatism rested upon faith in natural law, a transcendent order, tradition, a sense of place and an ingrained suspicion of internationalism with the adherents of classical liberalism. The ranks of classical liberals included, for example, Friedrich Hayek who, although regarded as one of the founding fathers of contemporary conservatism, was amongst those who eschewed the label. In his essay, Why I am Not a Conservative, Hayek argued that more was required than a mere brake upon further economic and social change. In place of conservatism's emphasis upon order and control, he emphasized individual liberty, the spontaneous and uncontrolled character of market forces and, as a 
corollary, limited government (Hayek, 1960). Fusionism not only accommodated but sought to reconcile both traditions by stressing the interdependence of freedom and order.

Against this background, particular moments in the 1980s, such as the passage of the 1981 Kemp-Roth tax cuts and Reagan's injunction to "tear down this wall", have taken on a quasi-mythic significance. The former are said to have presaged the eventual economic recovery and the latter anticipated the collapse of the Soviet bloc just three years later. And certain aphorisms such as "The most terrifying words in the English language are: I'm from the government and I'm here to help" are still ritually invoked by many.

\section{BEYOND THE BELTWAY}

The impact of Reagan and Reaganism should not, however, be seen as only a Washington DC Beltway phenomenon. In recent years accounts of contemporary conservatism have moved beyond Washington DC, with the publication of studies based upon party conventions, interests, lobbies and elected officials, with some legitimacy, labelled "top down". They tend to imply or suggest that "elite funders, Republican strategists, think tanks, and well-funded mass mailings were all that really mattered to explain the political prowess of the Right" (McGirr, 2011: 766). In contrast, "bottom-up" or grassroots studies have gained in scholarly legitimacy. Certainly, at the least, they provide an important counterweight to those accounts that are more "top down" in character.

The realignment processes in the south as whites in the former Confederacy abandoned the Democrats in the wake of the civil rights revolution are an important part of the story. Where Democrats survived in the south it was generally in solidly minority districts or through the built-in advantages given to incumbents. "Bottom-up" studies have tracked the long-run impact of urban change processes, discontent among "suburbanites" in areas such as the upper south and southern California, shifts in mass opinion and grassroots protests (Phillips-Fein, 2011: 727). They include surveys of the backlash "counter-movement" politics that emerged in response to the social upheavals of the 1960s and 1970s. They have also been attentive to the emergence, especially from the late 1970s onwards, of evangelical Protestantism as a core Republican constituency. There have also been studies of the "tax revolt" in California and the ways in which it was structured and shaped by the growth (through the underwriting of mortgages, measures that ensured racial homogeneity and the building of "branch plants") of the industrial suburbs and a form of conservative homeowner politics that was premised around the pursuit of low direct taxation rates (Self, 2006). 


\section{THE REAGAN REVOLUTION}

Overall, however the rightward shift is understood, the Reagan era is almost always hailed as a "revolution". As has been seen, there is a stress upon radical change in terms of regime style, the direction of public policy and electoral realignment. Certainly, the scale of overall change should not be underestimated. There is, first, a sharp contrast between the Reagan years and preceding Republican administrations. Those serving in Richard Nixon's administration (1969-1974) may at times have spoken in abrasively populist terms, lashed out at the counter-culture, and played an important part in creating the Republican electoral coalition that has endured to this day, but it also incurred the chagrin of conservatives by making "big government" bigger still. Both the Environmental Protection Agency (EPA) and the Occupational Safety and Health Administration (OSHA) were founded in 1970 and are widely seen by conservatives as the epitome of bureaucratic interventionism. Even when disregarding the Watergate debacle, the rapprochement with "Red China" and the eventual process of disengagement from Indo-China, few if any on the right look back on the Nixon administration in warm or positive terms.

Second, the tenor and the direction of public policy shifted in character from the 1980s onwards. It became commonplace to talk of the demise of the New Deal political order and the emergence of a conservative era (Edsall and Edsall, 1991; Morgan, 1994; Wilentz, 2008). ${ }^{1}$ Whereas the period that followed in the wake of the New Deal and the Second World War was shaped by the expansion of federal power and governmental responsibilities, the proclaimed (if largely unfulfilled) goal of public policy turned from the late 1970s towards the dismantling of "big government". Increasingly, if political discourses are considered, there were relatively few questions about the legitimacy or feasibility of this as a policy goal and it was eventually embraced across much of the spectrum. There was only muted dissent from the left when Democratic President Bill Clinton announced in his 1996 State of the Union Address that "the era of big government is over" (Clinton, 1996). Indeed, Clinton's “third

\footnotetext{
1 The "new right", Reaganism and the other right-wing strands that came to the fore from the 1970s onwards, constituted a particularly assertive and abrasive form of conservatism that was framed as a collective effort to reassert the principles upon which the United States was founded and owed much more to the classical liberalism that had been said by Louis Hartz to define the American nation than to the organic forms of conservatism that are often cited in European usages of the term. It should also be noted that conservatism is not synonymous with "the right". Accounts rightly draw dividing lines between conservatism, the "radical right" and in some instances, the "far right". Thus, militia movements or some now aligned with the "Alt-Right" would not be understood as conservative.
} 
way" politics seemed to be an important victory for conservative thinking insofar as they represented the taming of the Democratic Party and an implicit repudiation of the "tax and spend" politics that had been pursued, (albeit with less vigor and consistency than conservative accounts often suggested), in earlier years. Even though many commentators asserted that the 2008 financial crisis ended the Reagan era and the forms of neoliberalism around which it was structured, their claims turned out to be premature (Stiglitz, 2013). Once the immediate dangers posed by the crisis had passed, there was, if anything, a more forceful assertion of the market fundamentalism that had defined the 1980 s and the post-Reagan years. While there were differences about the speed and intensity of the "austerity" project, it was at times, despite the polarization of recent decades, a bipartisan effort. The reduction of the federal government's budget deficit had, by 2010, become a paramount public policy goal for policymakers from both parties (Ashbee, 2017).

There were, furthermore, other shifts during the Reagan years that went beyond policy and partisanship. They bequeathed a conservative infrastructure of periodicals, think-tanks, advocacy organizations and the Fox News network. Although the movement had begun to take shape in earlier decades, it grew significantly during the 1980s and thereafter.

Importantly, the Reagan years also brought conservatism and Republicanism together. Indeed, they became increasingly synonymous. By the closing decades of the twentieth century, partisanship went beyond a social or regional affiliation and had become unambiguously ideological. Economic issues such as tax-cutting, social questions, most notably abortion, and matters of science such as climate change became political litmus tests. Although there have been tensions between Republican moderates (associated with the Republican Main Street Partnership and the Tuesday Group) and the Freedom Caucus on the right, many of the fractures amongst Republicans owed more to tactical or anticipated electoral considerations than to ideology. They were often hidden when the party was in a minority but came to the fore at the times when the party held the majority in one or both houses of Congress.

Furthermore, Reagan's political adversaries also recognized the significance of his time in office. Although their commentaries have inevitably been more grudging or critical in terms of their tone, many associated with the left have acknowledged Reagan as a transformative president. At the beginning of his 2008 presidential election bid, and to the chagrin of Hillary Clinton's rival campaign, Barack Obama argued that "Ronald Reagan changed the trajectory of America in a way that, you know, Richard Nixon did not and in a way that Bill Clinton did not. He put us on a fundamentally different path" (quoted in Adams, 2008). Others also pointed to the path-departing character of the Reagan era but, in representing it as a fundamental break with the New Deal and Great Society years, argued that contemporary economic and social 
problems had their roots in the policy shifts that, they asserted, the Reagan presidency ushered in. The administration's policies, they charged, fueled economic inequalities, thereby heralding the beginnings of a new "Gilded Age". De facto reductions in government programs added substantially to the risks borne by those on the lowest rungs of the economic ladder. The War on Drugs led to the mass incarceration of young black men. The covert forms of foreign policy that the Reagan White House pursued diminished the role of Congress and at the same time contributed, in for example Afghanistan, to later "blowback" (Johnson, 2004).

\section{CHECKS ON THE REVOLUTION}

Nonetheless, while the assertion that there was a Reagan "revolution" or ruptural break during the 1980s is widely accepted, the empirical realities of the Reagan administration's policy record are far more ambiguous. Indeed, almost every claim made for the Reagan era by its cheerleaders can be readily countered.

There is certainly as much evidence of continuity as of change. Early tax reductions were reined in by later fiscal adjustments. The size of government, measured in terms of its share of GDP, was bigger when Reagan left the White House than when he entered it. By 1989, not even one of the social programs created by Lyndon Johnson's Great Society (including Medicare, Medicaid, Head Start, consumer protection and civil rights legislation) had been eliminated or substantially reduced (Pierson, 1994). Indeed, the size of the federal civilian workforce grew during the 1980s, whilst at the same time both the federal budget deficit and the national debt reached record peacetime levels. Furthermore, the economic growth rates that had contributed to Reagan's 1984 re-election victory proved far from sustainable as the 1991 recession, which so badly damaged President George HW Bush's re-election prospects, abruptly illustrated.

Even Reagan's policy intentions may not have been as radical as his followers have claimed. Henry Olsen, for example, has charged that far from being a high-priest for the neoliberal revolution and the "night-watchman state", Reagan should be seen within the framework of New Deal politics. From this perspective, insofar as he sought a dismantling of state provision, it was limited to the curbing of some excessively bureaucratic or inefficient Great Society programs (Olsen, 2017).

Furthermore, Reagan's record on judicial appointments is not clear-cut. While he nominated Antonin Scalia (who drew on both textualism and originalism and was to be a bedrock for conservative judicial victories in subsequent decades) to the US Supreme Court and elevated William Rehnquist to the post of Chief Justice, he also appointed Sandra Day O'Connor and 
Anthony Kennedy who proved to be unpredictable swing votes on some social issues amidst the continuing struggles between different judicial factions. ${ }^{2}$ Despite the hopes of cultural conservatives, abortion continued, while reined in, to be a constitutional right. In international affairs, Reagan came close, at the 1986 Reykjavík summit meeting with Mikhail Gorbachev, to agreeing the total abandonment of nuclear weapons.

If the Reagan era was any kind of "revolution", it was therefore a very limited and partial one. In The Politics Presidents Make, Stephen Skowronek argued that history offers opportunities at times of crisis to those, such as Andrew Jackson, Abraham Lincoln or Franklin Roosevelt, who can remake the political, social and economic order. If the Reagan presidency is considered within this framework (and the "malaise" afflicting the US in the late 1970s is regarded as a major crisis dooming the former regime), there was a sizeable gap between the Reagan administration's reconstructive rhetoric and reality:

Reagan fell far short of the mark in revitalizing national government around his new priorities and opening a more productive course for development ... The institutional commitments of the liberal regime, though battered and starved, were not decisively dislodged, and their "entitlements" would continue to determine the range of political possibilities. (Skowronek, 1993: 428)

\section{ASSESSING THE REAGAN LEGACY}

The Reagan policy record was thus much more mixed in character than many conservatives and Republicans have been ready to concede. Hugh Heclo speaks of Reagan's "legacies" (indeed "mixed legacies") rather than a singular "legacy" (Heclo, 2008: 557). Nonetheless, this is not the way it is represented by large swathes of the right. In their eyes, Reagan had won the Cold War through a policy of unassailable strength, changed the complexion of the federal courts, checked the cultural changes unleashed in the 1960s, shrunk the state and freed the economy. Conservatives have readily acknowledged that much remained to be achieved but a direction of travel had been set.

Nonetheless, in the years that followed Reagan's terms of office, efforts to build upon his political legacy (as it had been constructed by the conservative movement) hit significant institutional and ideational obstacles.

2 Kennedy's nomination came after Reagan's initial choice, Robert Bork, was stymied in Senate. Bork would certainly have been a more consistently conservative voice on the Supreme Court than Kennedy proved to be. 


\section{INSTITUTIONAL OBSTACLES}

At times, the US's institutional structures provided opportunities for political actors and a basis for empowerment. The pivotal position of the courts and the role it was bequeathed in interpreting the Constitution's provisions allowed a conservative "counter-culture" to flourish. The "due process" (of law) and "free exercise" (of religion) clauses in the Constitution established a basis for home schooling that has been largely pursued by conservative parents who are seeking an alternative to the public school system. By 2012, about 1.8 million children (constituting 3.4 percent of the US student population aged between 5 and 17) were home-schooled, a figure that was more than double that for 1999 (Brown, 2016).

For the most part, however, institutional structures limited opportunities and imposed constraints. Although the contemporary institutional landscape owes much to the growth of the administrative state, the formal institutional framework bequeathed by those who wrote the Constitution continues to put substantial obstacles in the way of those, whether conservative or progressive, seeking the passage of legislation. Since the mid-twentieth-century years, processes of partisan polarization have compounded the effects of separated institutions. Although policy divisions are less rigid if foreign policy is considered, divided government can, because of polarization, constitute the death-knell for significant domestic policy legislation. ${ }^{3}$

Moreover, the challenges posed by the institutional landscape go far beyond this. Following the emergence of the "new institutionalisms", institutions are now widely understood as not only consisting of formal institutions such as the executive branch, Congress or state governments, but also more loosely as policy legacies. E.E. Schattschneider's classic 1935 study of trade policy included the dictum "new policies create a new politics" (Schattschneider 1963: 288). In using the phrase, Schattschneider reversed customary representations of political causality and spelled out the ways in which protectionist trade policies, such as those adopted by the US in the wake of the Wall Street crash of 1929, established legacies that, in turn, by creating winners and losers, limited the range of credible, feasible or legitimate policy options open to later policymakers. Schattschneider charted the ways in which, once protective tariffs were enacted, those domestic economic interests that gained from the "shelter" that tariffs gave them from foreign competition (and were therefore "winners") would then seek through lobbying and other forms of

3 Furthermore, federal as well as state laws are always potentially subject to judicial review by the courts. 
political persuasion to maintain those tariffs and other restrictions on trade. ${ }^{4}$ These industries thus came to "form the fighting legions behind the policy". Prevailing policy arrangements gain further traction and influence because, at the same time as the winners fight to maintain their advantages, "the losers adapt themselves to the new conditions imposed upon them, find themselves without the means to continue the struggle, or become discouraged and go out of business" (Schattschneider 1963, 288). In the language of more recent studies, policies became "sticky" or perhaps, as some accounts suggest, even subject to "lock-in" (Pierson, 2000).

Although there will be differences in the degree to which policies become entrenched, "stickiness" or "lock-in" does not mean that paths should be understood in deterministic terms. It is looser and there is always a degree of "play": "a path likely to be followed in the absence of other pressures ... There will be change and evolution, but the range of possibilities for that development will have been constrained by the formative period of the institution" (Peters, 2011: 73). Or, more succinctly: "path-dependent processes make some courses of action more likely and others less likely" (Hacker, 2005: 147). Nonetheless, the concept of path dependence suggests that policies may change in character over time but, seen in this way, change will likely take place within the bounds set by pre-existing policy arrangements.

Furthermore, the institutional landscape in the US, and thus the obstacles facing those who seek a frontal assault on the existing policy arrangements, has become denser over the past century. Although the New Deal had to navigate structures of power associated with race, class and gender as well as more formal, organized forms of opposition, contemporary reformers have to wrestle with patchwork policy regimes based upon different relationships between public and private provision. Furthermore, the partial character of the "Reagan revolution" left many federal government entitlement programs intact, thereby placing further obstacles in the way of Reagan's conservative successors (Pierson, 1994; Skowronek, 1993: 429).

\section{IDEATIONAL OBSTACLES}

Those seeking reform have to confront ideas and ideational orders as well as institutions. Ideas and institutions have at times been represented as independent of each other. From this perspective, they co-exist and, just as different

4 Nonetheless, concepts of "winners" (or "fighting legions" in Schattschneider's terminology) and "losers" are not set in stone. Although some institutional changes can create unambiguous outcomes, understandings of "winning" and "losing" are constructions and may be open to intense contestation. At the least, perceptions of gains and losses are more often than not clouded and equivocal. 
institutional orders may chafe and abrade against each other, so may ideational orders, or at the same time there may be friction and clashes between ideational and institutional orders (Lieberman, 2002). Actors seeking reform thus confront ideas as well as institutions. And, just as institutions can be deeply embedded, associated clusters of both cognitive and normative ideas can also prove highly sticky and resistant to change. Both institutions and ideas impose parameters on the range of public policy options that are deemed legitimate and can secure a place on the policy agenda, although at times there are established ideas or narratives upon which those seeking change can draw, employ strategically and mobilize.

What can be said about the ideational terrain facing conservatives over recent decades? Popular commentaries often describe the US as a classical liberal or, as it more usually described, conservative nation (Hartz, 1955; Micklethwait and Wooldridge, 2005). This implies that public sentiments, paradigms and narratives governing the public policy process offer boundless openings to those seeking to build upon and extend the Reagan revolution.

At first sight the concept of a "conservative nation" seems fitting. The proportion of ANES poll respondents describing themselves as "conservative" has long been a very large plurality and has hovered around 40 percent since 1972. In the post-Reagan era, the figure reached a peak of 46.8 percent in 1994 and 48.2 percent in 2010 . In contrast, the proportion of self-defined "liberals" has been around 26 percent (Aberbach, 2017: 15). Furthermore, as references to a classical liberal or conservative nation suggest, some of the propositions that define contemporary conservatism have a resonance that extends beyond the ranks of those regarding themselves as "conservative". If, for example, asked in generalized terms about the proper role of government, many subscribe to the assertion that government should be limited in character. In 2012, 60.4 percent (including about one-fifth of those calling themselves "extremely liberal") agreed with the statement that "the less government the better" (Aberbach, 2017: 44). In particular, support for smaller government has grown amongst Republicans as the party's ranks have become more ideationally uniform around some major "litmus test" issues. Thus, support for small government among Republican identifiers and those who lean toward the party has grown from 61 percent in 2007 to 78 percent in 2014. If asked about government aid to the poor, again a relatively broad and generalized issue, 69 percent of Republicans and those leaning Republicans asserted that it did "more harm than good" (Pew Research Center, 2015).

Nonetheless, the overall picture is less straightforward and more multifaceted than these raw figures suggest. There is significant backing for some specific government programs, particularly those established during the New Deal and Great Society eras. Social Security, the nation's most expansive welfare state program, has become known as "the third rail" in US politics as those 
who attempt retrenchment "touch it and die". In 2012, a clear majority backed maintaining Medicare in its existing form and based upon a government guarantee of health insurance benefits. A plurality opposed proposals to restructure Medicare through a simulated market using a voucher scheme. There was even greater backing for Medicaid (78 percent) although it is at times depicted as a residual program for those on low incomes (Stokes, 2013: 4).

\section{FRONTAL ASSAULTS: ADVANCES, DEFEATS AND COMPROMISES}

Given the obstacles that conservative reformers faced, landmark legislative victories were inevitably scarce. When they were secured, they were often adulterated by the necessity of either conceding policy points to Democrats or, alternatively, sharing the political credit for their passage. There were the tax cuts proposed and secured by George W Bush's administration in 2001 and 2003, although as Chapter 2 argues, these might be more properly understood as a demand-based boost to a sluggish economy rather than in supply-side terms. Furthermore, the right has taken the credit for, and secured political capital from, some of the policies pursued by the Democrats, such as the pursuit of deficit reduction during the 1990s that they argued laid a basis for economic growth in the latter half of the decade. Although both were signed rather than vetoed by President Clinton, they can also point to the passage of the 1996 Personal Responsibility and Work Opportunity Act that radically tightened the availability of welfare provision; and cultural conservatives drew succor from the Defense of Marriage Act, passed in the same year, which curtailed efforts to recognize and spread same-sex marriage.

Even more importantly, the changes to the composition of the US Supreme Court and the lower federal courts led to significant victories. Nonetheless, some of the Court's efforts to rein in the liberalism of earlier decades were more limited in scope than conservative activists would have hoped. Although the Court opposed race-conscious classification in successive affirmative action cases, it sought at the same time to manage tensions around the issue by allowing racial considerations to be a factor in shaping universities' admissions policies (Chinn, 2014: 283). Furthermore, to the chagrin of cultural conservatives, the implied constitutional rights to "privacy" and "liberty" were used to establish and then enlarge gay and lesbian rights through rulings such as Lawrence v. Texas (2003) and Obergefell v. Hodges (2015). ${ }^{5}$

5 Lawrence v. Texas, 539 US 558 (2003); Obergefell v. Hodges, 576 US _ (2015). Changes in the character of the federal judiciary and the US Supreme Court in particular should also be considered. The Supreme Court tilted rightwards through the appoint- 
Tax cuts aside, the right was less keen to rally around some of the other measures passed during George W Bush's administration. They were politically adulterated. While Bush secured some legislative victories, their character was such that they were not always fully or unreservedly embraced by the conservative movement. Indeed, they represented untidy (and, in a highly partisan era, unusual) compromises between sections of the left and right. The No Child Left Behind Act of 2001 was passed with bipartisan support (Senator Edward Kennedy was a co-author) and, to the chagrin of many on the right, enlarged the federal government's role in school education. The 2003 Medicare Prescription Drug, Improvement, and Modernization Act incorporated some conservative health policy innovations, but it appeared, through the creation of Medicare Part D, to expand federal entitlements still further so as to cover prescription drugs (Jaenicke and Waddan, 2006).

There were also outright defeats for the right. The Democrats made some legislative headway during the windows of opportunity offered when the party not only held the White House but had a majority in both chambers of Congress. Although health care reform had to be abandoned, there were personal and corporate tax increases during Clinton's first two years in office (1993-1995); and Obama's first two years of office (2009-2011) allowed the passage of the fiscal stimulus, healthcare reform and tightened financial regulation. And as noted above there were also judicial defeats that were felt most acutely by social conservatives.

Against this background, major conservative reform efforts had to be abandoned. Proposals to secure a constitutional amendment requiring the federal government budget to be balanced, which had been included with the 1994 Contract with America, failed in the Senate, although it might be argued that the pursuit of an amendment was a way of reducing the pressure on lawmakers to take action on the deficit during annual budget deliberations. George W Bush's 2005 proposals to partially privatize Social Security had to be abandoned. Furthermore, many of the calls for legislative reforms circulated by the major conservative thinktanks, such as proposals to impose drastic expenditure reductions, balance the budget over a sustained period and eliminate the national debt, increase labor market flexibility, enact supply-side reforms, pursue "pro-growth tax reform", further limit the availability of welfare, bolster "states" rights", dismantle the "regulatory state", reform or perhaps end entitlement programs such as Medicare, Medicaid, and Social Security,

ments of Clarence Thomas in 1991 (in place of Thurgood Marshall) and Samuel Alito in 2006 (in place of Sandra Day O'Connor), although the bench still remained divided at least until the appointment of Justice Brett Kavanaugh in October 2018, and many of its key social and cultural rulings continued to be unpredictable ahead of their issuance. 
abolish certain government departments (Commerce, Education, and Energy were often cited as targets), and rebuild US military capacity, were circulated during Republican presidential primary contests, but then failed to make significant headway.

Furthermore, despite the commitment to deregulation, the policy achievements were relatively limited. Successive Republican administrations failed to uphold many of the promises to scrap regulations that had been made on the campaign trail. The deregulatory process has often been hesitant, partial and uneven. Deregulation in one sector has often been accompanied by regulation or re-regulation in other sectors. This was partly because of the changed national security situation after the attacks of September 11, 2001 that put new demands upon government. There were also corporate fraud scandals that seemed to demand a regulatory response. Sometimes deregulation, such as President George W Bush's faith-based and community initiative that permitted religious organizations to compete for social service contracts, necessitated the introduction of an accompanying regulatory regime (DeMuth, 2011: 315). Similarly, both the No Child Left Behind Act and the expansion of Medicare required regulatory governance. It was also because presidents sought, for electoral reasons, to maintain or reposition their political brand through either the issuance or maintenance of particular regulations (thus, George W Bush retained the Clinton administration's decision to protect large amounts of land as national monuments). Most importantly, legislation has a logic of its own that outlasts presidential officeholders and periodically requires regulatory adjustment. As a 2008 report issued by the Heritage Foundation noted, the federal government had imposed almost $\$ 30$ billion in new regulatory costs since 2001 (Gattuso, 2008).

Thus, and this is testimony to institutional resilience, "big government" remained big. Grover Norquist, the highly influential conservative organizer who has played an important role in creating and maintaining structured networks that bring together different movement organizations and currents, once declared: "I don't want to abolish government. I simply want to reduce it to the size where I can drag it into the bathroom and drown it in the bathtub" (Avlon, 2012). The "size" of government is of course difficult to measure, and proxies are open to debate, but, despite conservative hopes, government spending levels have, over a long-run period, remained broadly constant as a share of GDP. ${ }^{6}$ General government spending (consisting of federal, state and local

6 Given the ageing of the population (although median age has moved upwards at a slower pace and remains lower than in many European countries), and the greater demands that this imposes upon the state, it might credibly be argued that these figures necessarily represent a fall in the scale and quality of social provision, but they are still a very long way away from Norquist's declared goal. 
government expenditure) represented 36.12 percent of GDP in 1989 when Reagan left office (up from 35.1 percent in 1981). It was up to 37.06 percent in 1990, down to 33.72 percent in 2000 (largely as a consequence of economic expansion during the late 1990s), up to 42.94 percent in 2010 as the Great Recession took its toll, and down to 37.74 percent in 2015 (OECD Data, 2017).

\section{INCREMENTALISM AND VISIBILITY}

This does not mean, however, that the right secured little or nothing. Instead, as studies of policy change that move beyond crude models of path dependence suggested, there were gradualist and subterranean forms of policy change the effects of which only became fully evident with the passage of time. As Jacob Hacker notes, in dense institutional landscapes, gradualism may well be the only viable strategic option open to political actors:

actors who wish to change popular and embedded institutions in political environments that militate against authoritative reform may find it prudent not to attack such institutions directly. Instead, they may seek to shift those institutions' groundlevel operation, prevent their adaptation to shifting external circumstances, or build new institutions on top of them. (Hacker, 2004: 244)

Although different terms are sometimes used within different scholarly fields and sub-fields, gradualism has rested in particular on processes of policy drift and layering. "Drift" refers to processes by which formal institutional structures and policy arrangements remain largely the same, but the contexts and settings within which they operate shift in character, thereby changing the impact of those arrangements and structures. Thus, during the relatively long periods when the federal minimum wage remained unchanged, it lost value in real terms as inflation took its toll. Reflecting Reagan's skepticism over the value of mandated minimum wages (Clines, 1983), the nominal federal minimum wage remained at $\$ 3.35$ an hour from 1981 through 1989 , which was a reduction in real terms, in constant 2015 dollars, from $\$ 8.71$ to $\$ 6.38$ (Kurtz and Yellin, 2015). Federal policy thus changed in character by remaining unchanged. Jacob Hacker has similarly explored the ways in which, over time, individuals were exposed to growing "social risk" and were thus more vulnerable because policy arrangements were not updated to match changes in the labor market and society:

Although most U.S. public social programs have indeed resisted radical retrenchment, the American social welfare framework has also, in crucial areas, offered increasingly incomplete protection against the key social risks that Americans confront. (Hacker, 2004: 243) 
Policy drift has been at work in other arenas. The failure to update corporate tax legislation inevitably led to the greater use, exploitation and institutionalization of loopholes. Thus, even by the end of the 1980s, the corporate tax regime was characterized by "thousands of exemptions, deductions, credits, minimum taxes, and special rules that litter the tax code. Indeed, these tax expenditures are so significant to the system that they profoundly shape its very structure" (Steinmo, 1989: 509-510).

Conservative "layering" strategies rest on the creation of private market-based alternatives that are created "on top" of existing forms of governmental provision. Over time, the new private alternative will weaken and undermine support for governmental programs among the middle classes by drawing them away and thereby giving governmental programs more of a residual character so that they only provide for those in most dire need. Thus, as Wolfgang Streeck and Kathleen Thelen note:

The actual mechanism for change is differential growth; the introduction of new elements setting in motion dynamics through which they, over time, actively crowd out or supplant by default the old system as the domain of the latter progressively shrinks relative to that of the former. (Streeck and Thelen, 2005: 24)

The changes in the US tax regime allowing savings for old age or other purposes through individual retirement accounts (IRAs) and 401(k)s constituted a form of "layering". Although Social Security provision remained formally intact, it lost some of its former importance in people's lives as private, commodified savings opportunities emerged as a parallel system, albeit one based upon the privatization and individualization of risk (Hacker, 2004: 255-256). ${ }^{7}$

Republicans have seen developments within the pension and savings regimes as a model that can be followed in other policy arenas. Newt Gingrich, former Speaker of the US House of Representatives, was evidently thinking in these terms when he talked of encouraging private health insurance provision among individuals approaching or in their old age. Gingrich believed that private provision would grow over time and thus saw this as a way of eliminating Medicare, the government single-payer insurance system:

Now, we don't get rid of it in round one because we don't think that that's politically smart, and we don't think that's the right way to go through a transition. But

7 To this, it should be added that technological shifts, and in particular the development of an app-based economy in the twenty-first century that exposed sections of the labor market to processes of "casualization" (or growing "precarity"), have also done much to hasten the spread of unregulated market forces and commodification processes. 
we believe it's going to wither on the vine because we think people are voluntarily going to leave it - voluntarily. (quoted in The New York Times, 1996)

Similarly, the Republicans' 2012 vice-presidential candidate and later Speaker of the House, Congressman Paul Ryan, spoke during the election campaign and in his 2011 plan (The Path to Prosperity) of "saving" Medicare by putting forward a voucher scheme that would introduce a simulated market for healthcare amongst senior citizens, which would permit individuals to choose between Medicare and private providers (Tanner, 2011). Critics charged that the vouchers would fail to keep pace with rising medical costs, forcing senior citizens to pay increased sums, and that Medicare might be left as a largely residual system providing only limited assistance for those who had difficulties securing private health cover as those on high incomes or in good health defected to other providers.

By definition, gradualism is a long-run process, and the results that were yielded were only partially visible as they emerged but could have significant long-term consequences. For example, the "right-to-work" laws passed in more than half the states, which prohibited agreements requiring union membership in a firm, together with pressures in some sectors generated by deregulatory shifts and alongside other, broader, processes, including the decline of manufacturing, played an important part in fueling a decline in union membership (Manzo and Bruno, 2017: 1). The proportion of workers in unions had fallen to 10.7 percent in 2016 and the figure for the private sector was just 6.4 percent (Bureau of Labor Statistics, 2017). Union membership was thus increasingly confined to the public sector. There were other shifts. Increasing income inequality, in significant part a function of the tax regime, ensured that those at the higher end of the income scale received, as conservative representations depicted it, increased economic rewards for their skills and entrepreneurship.

There were other reasons why conservative reforms often lacked visibility. The movement engaged in venue-shopping. Faced by the challenges associated with the national institutional landscape, particularly that associated with the executive and legislative branches of government in Washington DC, they sought out alternative "access points" that might prove more pliable. There were some opportunities within the federal and state courts. The Institute for Justice, a conservative advocacy organization, has played a pivotal role in using the courts to restrain the powers of government and litigating around core public policy issues such as eminent domain and interstate commerce. The Obama administration's signature policy accomplishment, the 2010 Affordable Care Act (ACA) ("Obamacare"), was immediately challenged in the courts, with over half the nation's states joining the litigation. While, to the chagrin of the right, the US Supreme Court upheld much of the ACA in both National Federation of Independent Business v. Sebelius (2012) and King 
v. Burwell (2015), ${ }^{8}$ the former decision saw the Court undermine the ACA's efforts to force states to expand their Medicaid programs.

Furthermore, where legislation was passed at state level, its visibility was limited because it was not framed in overtly ideological terms. Instead, legislation was driven by competitive liberalization that seemed to give little political discretion to policymakers from either party. Tax concessions in one state might, so as to spur corporate investment, compel other states to adopt similar measures. There would thus be a domino effect. The American Legislative Exchange Council (ALEC), within which corporations play a major role alongside conservative Republicans, promotes "model bills". It claims that over a thousand such bills are introduced every year and that one in every five secures enactment into law.

\section{ANGER, DISENCHANTMENT AND SPLINTERING}

There was therefore significant policy change during the post-Reagan years but, given its incremental and often subterranean character, it had only limited political visibility. The sense that there had been few achievements since the Reagan years fueled increasing distrust, anger and resentment across the right.

That anger has been intense at times, in particular during the periods when the Democrats held the White House. The bitter hostility towards Bill Clinton gave rise to conspiracism and culminated in impeachment proceedings against him. Anger against Obama reached a crescendo as Birtherism secured traction and the Tea Party movement established itself: 92 percent of Tea Party supporters said that Obama was leading the country "towards socialism". Only 41 percent accepted that he had been born in the US (The New York Times/CBS News, 2010: 24).

Conservative anger has had three defining characteristics. First, despite the intensity of conservative anger, and the fueling of tensions between grassroots activists and Republican leadership elites, it has generally taken an unorganized and unfocused form. This may in part be because of the conservative movement's organizationally hybrid character. Although it incorporates spontaneous grassroots elements and is not simply political "astroturf", it is more elite-directed than the concept of a "movement" customarily suggests. And some of the elites that played a part in shaping the character of the movement shrank from head-on confrontations and sought accommodations with Republican members of Congress. In a number of cases, for example, financial contributions to candidates were spread across a number of primary chal-

$8 \quad$ National Federation of Independent Business v. Sebelius, 567 U.S. 519 (2012) and King v. Burwell, 576 U.S._(2015). 
lengers, thus giving the incumbent an advantage (Boatright, 2014: 1). Thus, efforts to unseat Republican incumbents generally proved fruitless. There was a dramatic moment when in June 2014 the House Majority Leader, Eric Cantor, lost the Republican primary to a challenger associated with the Tea Party movement. Nonetheless, this uprising against the party "establishment" was not replicated.

Conservative identifiers also struggled in the years after Reagan to find a credible presidential contender. George HW Bush, Bob Dole, George W Bush, John McCain, and Mitt Romney were all regarded as "establishment" candidates. With the partial exception of George W Bush's 2004 campaign, they tacked towards the middle ground and sought to soften their image once the primaries had been concluded. They all won conservative votes but it was Alaska Governor Sarah Palin's quasi-autonomous "rogue" 2008 vice-presidential campaign that sparked excitement and enthusiastic commitment. In mid-October 2008, she had an 85 percent favorability rating amongst both conservative Republicans and white evangelicals, and was for a period regarded as a future presidential contender (Pew Research Center, 2009a).

Second, new technology and the changing character of the media increasingly offered new mobilizing opportunities. Put another way, there are now many more access points open to activists and strong identifiers allowing them to subject lawmakers to increasing scrutiny and pressure. Mobilizations can now be organized in minutes rather than weeks. The growth of cable news and social media laid a basis for what the conservative commentator, the late Charles Krauthammer, called "hyper-democracy". Former gatekeepers have disappeared. Indeed, it can be credibly argued that there are now no gates (Nash, 2016).

The growing importance of cable news and social media contributed to a parallel development. Conservatism became an increasingly closed and self-referential community. There is a reliance on limited sources of information and there are processes of inter-generational socialization. A Pew Research Center study found that 47 percent of "consistent conservatives" cited Fox News as their main source for news about government and politics, and 88 percent trusted it as a news source. Two-thirds (66 percent), a much higher proportion than found amongst those on the left, said that most of their close friends shared their views on politics and government (Mitchell, Gottfried, Kiley and Matsa, 2014). The strengthening of identity over time has in turn had consequences for conservatism's boundaries. Whereas they were relatively loose and permeable, the strengthening of identity and the emergence of totemic beliefs defining who is, or is not, a conservative seem to have created more impermeable boundaries that may well attach significant social costs to exit (Van Stekelenburg, 2013: 221). 
Hence, conservative elites have faced growing challenges. Given this, they have come to adopt more oppositional approaches, extended the range of issues that are subject to partisan conflict and sought more radical legislative goals. While primary challenges to Republican incumbents were largely unsuccessful, the Tea Party movement that emerged in early 2009 mobilized quickly and forced conservative elites to move sharply rightward. In the run-up to the 2010 mid-term elections, the House Republican candidates embraced the Pledge to America. Although it focused more on policy rather than Congressional procedures, the Pledge consciously sought to replicate the 1994 Contract with America by translating the themes and rallying calls that defined the Tea Party movement into legislative action. It included commitments to tax concessions, the rolling back of government spending, the repeal of Obamacare, and a ban on any government spending for abortions. More broadly, given the visibility of most Congressional votes and the frequent public scoring of members by conservative advocacy organizations, very few Republicans office-holders were ready to vote with the Democrats or seek out bipartisan options.

Third, conservative and Republican anger was fueled by the resentments of the demographic groupings and constituencies to which they were tied. While backing for formal, institutionalized or de jure discrimination is more or less negligible, (even in 1978 just 4 percent of self-defined conservatives supported segregation), there are associations between conservatism, Republicanism and negative racial attitudes (American National Election Studies, 2017a). ${ }^{9}$ Although, for example, there was a dramatic decline in the preceding decades, 27 percent of white Republicans still said in 2012 they would oppose a close relative marrying a black person. Similarly, 57 percent said blacks lacked the motivation to pull themselves out of poverty and 32 percent said they thought society was spending too much money trying to improve blacks' conditions. ${ }^{10}$ It is furthermore difficult to escape the conclusion that the intense personal animus towards President Obama, particularly that expressed by the Birther movement, was driven by racially-edged sentiments and a suspicion that Obama was regarded by many conservatives as an illegitimate outsider because of his race (Tesler, 2016).

Alongside the effects of race and ethnicity, the part played by age in structuring conservatism's political perceptions should also be considered. In 2012, self-identification as a conservative (including "leaners") was highest (at 48

9 Surveys of the racial attitudes pose some obvious methodological challenges. In particular, there may be social desirability bias whereby respondents are reluctant to express sentiments they fear may be regarded critically.

10 However, it is striking that the survey revealed that while the numbers were lower (although not always by much), a significant proportion of white Democrats also shared these attitudes (Silver and McCann, 2014). 
percent) amongst those born between 1927 and 1942, and just 21 percent among those born in 1991 or later (American National Election Studies, $2017 \mathrm{~b}$ ). There is evidence to suggest that intergenerational fears about the prospect of redistribution to the young may have played a part in propelling the right. Survey interviews indicate that many Tea Partiers, who were disproportionately drawn from the older age-cohorts, saw the young as overly entitled and unwilling to work sufficiently hard (Skocpol and Williamson, 2012: 72-74). Similarly, income differentials contribute to the shaping of attitudes. Despite shifts further down the scale, identification as a conservative remains highest (at 42 percent) amongst those in the highest 32 percentiles (American National Election Studies, 2017b). And they subscribe to the belief that the poor are undeserving and subject to moral hazard. A poll suggested that over three-quarters of conservatives (aggregated across different sub-categories) agreed with the proposition that "poor people have it easy because they can get government benefits without doing anything" (Ingraham, 2014). The 2010 study of Tea Party supporters found that a major source of hostility towards the Obama administration was the belief that it unjustly favored the poorest groupings (The New York Times/CBS News, 2010: 24).

\section{THE WHITE WORKING-CLASS}

While the median Republican voter is drawn from the higher-income groupings, the white working-class, most particularly that fraction in the southern states, is disproportionately Republican. The era when "white ethnics" in the urban north were regarded as part of the New Deal coalition and Democrats still had hold in the white south are long forgotten. In 2008 and 2012, Barack Obama won just 40 percent and 36 percent respectively of the white working-class vote across the country (Edsall, 2014a). ${ }^{11}$

Such voters are in many ways "conservative" as well as Republican. A Democracy Corps poll found that if the white working-class is defined on the basis of education, they agreed, by a 46.2 percentage point margin, with the statement "When something is run by the government, it is usually inefficient and wasteful". The survey also found that white working-class opinion was "conservative" on a range of other issues, including military spending, gay rights, immigration, public works spending and the potential expansion of pre-K classes (Edsall, 2014a).

11 Note, however, that there are significant methodological challenges in defining the white "working-class". Some studies use income levels whilst others consider educational attainment. 
Nonetheless, there are limits to the "conservatism" of the white working-class. Whilst there was generally strong backing for issue positions associated with cultural conservatism and opposition to affirmative action particularly in the south (although the issue salience of both may be limited), some economic issues suggested greater ambiguity (Edsall, 2014a): 70 percent believed that the economic system unfairly favored the wealthy; 62 percent supported an increase in the tax rate on those households with incomes of over \$1 million per year (Jones and Cox, 2012: 4-5). Indeed, like others, whites become more conservative as income levels rise (Bartels and Cramer, 2018). A 2016 poll found that 69 percent of whites earning less than $\$ 30,000$ felt that the federal government was not doing enough to help them and people like them. Amongst those earning $\$ 75,000$, the figure was only 31 percent (Holmes, 2016).

The "Great Recession" inevitably compounded the difficulties facing the white working-class. If, for example, wealth is considered, the median net worth of low-income whites was cut by almost half between 2007 and 2016, whilst the figure remained broadly constant for low-income Hispanics and blacks (Chen and Toh, 2017). At the same time, of the 11.6 million jobs created during the recovery from the beginning of 2010 onwards, 11.5 million (99 percent) went to workers with, at the least, some college education (Carnevale, Jayasundera and Gulish, 2016: 1). Just 100,000 jobs, however, went to those who had never attended college. While the new technology sector prospered, the decline of long-established manual industries continued apace. These industries had been largely constructed around the white, male, working-class, and in the post-war decades they had paid a family wage that was more or less sufficient to support children and allow wives to remain at home or engage in part-time employment. There had been an implicit promise of long-run job security, a vista of continuing growth, and a "contract" between the worker and the state that socialized the risks posed by illness, old age and unemployment.

There was, however, relatively little discussion of the white working-class by commentators in the years before the 2016 presidential election cycle. As Chapter 6 records, there were sporadic populist and nationalist outbursts (most notably Pat Buchanan's presidential campaigns) but they dissipated. Nonetheless, the white working-class had a significant weight within the Republicans' electoral bloc. Furthermore, its anger and resentment were shared by other Republican voters and many who continued to cast a Democratic vote. While this form of populist politics was long-hidden or overlooked, it came to the fore in 2016 as the anger of grassroots conservatives and Republicans, as well as that of the white working-class along with the mechanics of the Electoral College, gave Donald Trump his victory. 


\section{FOREIGN POLICY AND EXOGENOUS SHOCKS}

Much of the preceding discussion and most of the chapters in this book are concerned with domestic policy. They consider the Reagan legacy in terms of economic and social policy, the role of the state, the battles that collectively constitute the "culture wars" and, within this context, the shift towards populism and nationalism. These chapters chart the fortunes of the conservative movement and consider both its policy victories and frustrations.

In certain respects, foreign policy demonstrates similar characteristics. As Chapter 4 records, the Reagan legacy was as ambiguous in foreign policy as it was in other arenas. The Reagan administration demonstrated flexibility as well as animosity towards Moscow. In some respects, the administration of Jimmy Carter, at least in its latter stages, followed an equally tough, perhaps (as in the case of grain sales) an even tougher stance towards the USSR than did Reagan. By the end of the Reagan presidency, many conservatives, including some in his own administration, had become disenchanted with Reagan's policy of sustaining a friendly dialogue with Mikhail Gorbachev.

Similarly, although conservatives generally favor high levels of defense spending, take a "hard line" stance towards adversaries, and celebrate what is represented as the Gipper's victory in the Cold War, there have been significant policy differences across the right (Dueck, 2010). Some conservatives have always supported limited engagement with foreign powers, whilst others saw more of a role for the US. The Tea Party, the main conservative upsurge of the second decade of the twentieth century, was split between advocates of foreign policy restraint and supporters of putatively "Reaganite" foreign policy assertion (Mead, 2011). Given all of this, the concept of a "conservative" foreign policy is, as Chapter 4 notes, very difficult to identify or define.

Nonetheless, despite these affinities, the foreign policy experience of American conservatism, from Reagan to Trump, was in other respects qualitatively different to the domestic experience. This is scarcely surprising. Foreign policy generally impinges on the everyday experience of most Americans to a far lesser extent than social and economic issues. It has lower salience, and is thus essentially an elite affair. Furthermore, presidents enjoy enormous discretion in foreign policy, not least because much foreign policy (at least beyond the purview of the defense and foreign aid budgets) does not require new legislation. The constraints on presidential foreign policy derive as much from the pressures of global power distribution as from the US Constitution or domestic political pressures.

Even more importantly, the foreign policy agenda and the policymaking process were, between 1988 and 2016, largely driven by major, in some cases system-shattering, external shocks. The end of the Cold War transformed the 
international environment. The 9/11 terror attacks of 2001 set the parameters of US foreign policy for at least the following seven or eight years. The postCold War acceleration of, especially economic, globalization profoundly upset conservative attitudes towards international trade, calling into question traditional support for free trade. These external shocks altered the entire global context of US foreign policy, destroying much of the relevance of any lessons to be drawn from the experience of the Reagan administration.

The period under consideration in this book also saw radical shifts in how conservatives understood the nature and extent of America's global power. When Reagan came into office in 1981, commentators were still preoccupied with post-Vietnam War narratives of putative American decline. The Carter presidency, in particular, was seen by many on the right as essentially concurring in the notion of American decline. By the turn of the century, the narrative had turned 180 degrees. With its Cold War victory under its belt, America now faced its "unipolar moment" (Krauthammer, 1991). The 2003 invasion of Iraq was undertaken, at least partially, as part of a move to reshape the Middle East, made possible by America's unprecedented global strength. The subsequent floundering of US policy in Iraq rekindled notions of global decline. Such notions were greatly reinforced by the rise of China and by the impact of economic globalization. For many conservatives the Obama administration appeared a re-run of Jimmy Carter: an administration which accepted the fact of American global decline, and indeed which based its policies around the acceptance of such decline. Such was the background to the Trump campaign of 2016 and its promise to "make America great again".

\section{THE AMERICAN RIGHT AFTER REAGAN}

This introductory chapter has argued that although many of the policy shifts were far more limited in character than some assert, the Reagan era left an important political legacy for conservatives. Despite the constraints imposed by institutional, ideational and policy legacies, it set off a chain of significant structural changes and reforms. While major parts of the conservative policy agenda, including the dismantling of government social provision, remained unfulfilled three decades after Reagan left office, the state no longer ameliorated economic and social risk in the way that it had during the mid-twentieth-century years. Large swathes of the population were much more exposed to the uncertainties associated with neoliberalization.

Nonetheless, although there were significant changes during the post-Reagan years, they lacked political visibility. The reforms were for the most part gradual and subterranean in character. If conservatives looked overseas, the limits on American power and the rise of challengers were much more readily 
evident than the US's capacity for action. In the absence of visible victories, there was a strong sense that the US was losing ground.

There was a comparable lack of political visibility in the foreign policy arena. As Chapter 4 charts, foreign policy thinking was largely driven by a succession of external shocks rather than deliberative choice. The US thus appeared to be the victim of forces and circumstances. Responses to those shocks were, however, refracted through long-established conservative and Republican foreign policy traditions. Furthermore, those shocks, most notably the attacks on September 11, 2001, opened up particular structures of opportunity for different factions within the right.

Perceptions of the US's global role during the Obama years, and the discourses that defined the 2016 election campaign, brought conservative nationalism to the fore. Thus, the Trump administration's foreign policy stance marked a significant and conscious departure from its predecessors although, having said that, it drew - through a process of ideational bricolage - upon earlier impulses and currents, in particular neo-Jacksonianism, the "America First" tradition, Patrick J Buchanan's campaigns in the 1990s, and some of the themes that defined Congressman Ron Paul's opposition to overseas interventionism.

The absence of political visibility in both the domestic and foreign policy arenas had profound consequences. It created a gap between expectations and perceived results that in turn fueled conservative grassroots anger and resentment while leading to a splintering amongst elites. New technology, changing sources of funding, and alternative bases for political mobilization gave all these sentiments further opportunities for expression. At the same time, the white working-class, which formed a significant part of the Republican electorate, faced the economic consequences of globalization and the "Great Recession". Conservatives, whether social or economic conservatives, reacted against the perceived injustices and betrayals of the Obama years.

The chapters that follow consider conservative and Republican policy development in the decades that followed the Reagan era. They survey economic policy, conservative efforts to reduce and restructure the state, the waging of the "culture wars" and the splintering of foreign policy positions. They survey policy goals and the ways in which those goals were frustrated by institutional and ideational barriers as well as exogenous shocks. On the basis of this, Chapter 6 considers the anger that was engendered, the ways in which that anger found political expression, and the openings that allowed populism and a strident nationalism to challenge the established post-Reagan conservative paradigm.

Seen in this way, the Trump presidency represented a sharp break with the forms of conservatism and Republicanism that were ascendant from the 1980s onwards. The book dissents from suggestions that, despite his many distinct 
personality traits, his period of office, if judged in policy terms, is an orthodox or "ordinary" Republican presidency (Herbert, McCrisken and Wroe, 2019). While the legislation that has been enacted and the executive actions (a category that includes executive orders but also proclamations, statements and other assertions of policy) have been limited and relatively "ordinary" in character, political "outputs" amount to much more than this. They include, for example, forms of political mobilization (relationships between party elites and the grassroots have changed profoundly), the capacity to set the agenda, and the shaping of narratives. Judged on this basis, and while some themes that the Trump White House pursued were anticipated well before the 2016 election, there is little that is orthodox or "ordinary" in terms of conservative and Republican discourses about the Trump presidency.

Given Trump's lack of "ordinariness", there is a case for suggesting that he should be regarded as a "disjunctive" president who seeks to hold together and maintain a weakened and vulnerable regime that is coming under political fire and, in doing this, seeks to offer a form of politics that is divided from his party's orthodoxy. Preemptive presidents oppose the existing regime but lack the opportunities for reconstruction. They cannot create sufficiently strong or broad coalitions (Skowronek, 1993). Seen in this way, Donald Trump's ascendancy might be taken to suggest that Reaganism has run its course.

Nonetheless, there may be a stronger case for arguing that the Trump presidency could represent more than this. Indeed, although the administration is pulled between different Republican constituencies and has had a character as mercurial as the president's personality, it could, at least in some respects, prove transformative rather than disjunctive. It has abandoned some of the defining tenets of Reaganite neo-liberalism, created new forms of political mobilization, changed the nature of party elites and the relationships between them, and brought forth a process of realignment within the Republican electoral bloc. That may be sufficient to lay the basis for a further regime or order. 